\title{
Pengaruh Kemasan, Kualitas Dan Harga Produk Susu Terhadap Kepuasan Dan Loyalitas Pelanggan PT. Dwimitra Usaha Global
}

\author{
Shandi Purwoko, Arif Haryana, Mariati Tamba \\ Program Studi Administrasi Bisnis Program Magister Universitas Respati Indonesia \\ Email : shandi_purwoko@yahoo.com
}

\begin{abstract}
ABSTRAK
Berbagai merek produk susu segar dengan teknologi pasteurisasi yang ada di pasar menyebabkan PT. Dwimitra Usaha Global perlu meningkatkan pemasarannya dengan baik terlebih produk ini masih baru. Hal ini menyebabkan persaingan antarperusahaan produk sejenis menjadi sangat ketat sehingga mengakibatkan produk susu produksi PT. Dwimitra Usaha Global banyak kehilangan pelanggan dan mengalami penurunan penjualan. Oleh karena itu perusahaan perlu mengetahui informasi terkait kepuasan, loyalitas dan pola pembelian konsumen untuk meningkatkan pemasarannya dalam memenangkan persaingan. Tempat penelitian dilakukan di PT. Dwimitra Usaha Global yang berlokasi di Lebak Bulus, Jakarta Selatan. Metode penelitian adalah kuantitatif dimana populasinya adalah orang yang datang untuk membeli produk susu di sekitar Jakarta Selatan yang berjumlah 110 orang sebagai sample. Teknik pengambilan sampel menggunakan Accidental Sampling, dan analisis data menggunakan software SmartPLS versi 3.0 PLS. Hasil penelitian adalah kemasan berpengaruh signifikan terhadap kepuasan pelanggan, kemasan tidak berpengaruh signifikan terhadap loyalitas pelanggan, kualitas tidak berpengaruh signifikan terhadap kepuasan pelanggan, kualitas tidak berpengaruh signifikan terhadap loyalitas pelanggan, harga berpengaruh signifikan terhadap kepuasan pelanggan, harga tidak berpengaruh signifikan terhadap loyalitas pelanggan, kepuasan pelanggan berpengaruh signifikan terhadap loyalitas pelanggan.
\end{abstract}

Kata Kunci: Kemasan, Kualitas, Harga, Kepuasan Pelanggan dan Loyalitas Pelanggan.

\begin{abstract}
Various brands of fresh milk products with pasteurization technology on the market have made PT. Dwimitra Usaha Global need to increase its marketing properly, especially since this product is still new. This causes the competition between similar product companies to be very tight, resulting in the loss of many customers of PT. Dwimitra Usaha Global's milk products and a decrease in sales. Therefore, companies need to know information related to satisfaction, loyalty and consumer buying patterns to increase their marketing in winning the competition. Where the research was conducted at PT. Dwimitra Usaha Global, located in Lebak Bulus, South Jakarta. The research method is quantitative where the population is 110 people who come to buy dairy products around South Jakarta. The sampling technique used Accidental Sampling, and data analysis used the SmartPLS version 3.0 PLS software. The results of the study are packaging has a significant effect on customer satisfaction, packaging has no significant effect on customer loyalty, quality has no significant effect on customer satisfaction, quality has no significant effect on customer loyalty, price has a significant effect on customer satisfaction, price has no significant effect on customer loyalty, satisfaction. customers have a significant effect on customer loyalty.
\end{abstract}

Keywords: Packaging, Quality, Price, Customer Satisfaction and Customer Loyalty 


\section{Pendahuluan}

Peningkatan kualitas sumber daya manusia Indonesia tidak hanya melalui peningkatan pendidikan dan pengetahuan. Namun, faktor gizi pun mempunyai peranan penting, karena gizi yang baik dan seimbang dapat akan menciptakan sumber daya manusia yang mempunyai kualitas yang lebih baik. Gizi yang baik dan seimbang dapat dipenuhi dengan mengkonsumsi makanan yang sehat dan mengandung vitamin, karbohidrat, protein dan lemak.

Sub sektor peternakan khususnya komoditi susu merupakan salah satu sumber gizi yang diminati, karena susu mempunyai kandungan gizi yang lengkap yang dibutuhkan oleh manusia untuk peningkatan kecerdasan, pertumbuhan dan kekuatan fisik. Namun pada sisi lain, susu adalah bahan makanan yang mudah rusak dan tidak tahan lama, sehingga diperlukan pengolahan dan penanganan yang lebih baik untuk menjaga kualitas susu.

Menurut Kotler dan Amstrong (2012) mendefinisikan "packaging involves designing and producing the container or wrapper for a product" yang artinya adalah proses kemasan melibatkan kegiatan mendesain dan memproduksi, fungsi utama dari kemasan sendiri yaitu untuk melindungi produk agar produk tetap terjaga kualitasnya. Pada produk Vito milk masih menggunakan plastik steril berukuran 1 liter.

Kualitas produk merupakan hal penting yang harus di miliki oleh setiap perusahaan jika ingin produk yang dihasilkan dapat bersaing di pasar untuk memuaskan kebutuhan dan keinginan konsumen. Kualitas susu pasteurisasi membuat produk tersebut bernilai jual lebih dibandingkan produk pesaing. Saat ini konsumen semakin kritis dalam memilih untuk mengkonsumsi produk mana yang akan dibelinya. Dengan produk yang berkualitas serta banyaknya varian susu pasteurisasi yang dapat diolah menjadi yogurt dan kefir, bukan tidak mungkin untuk menarik minat masyarakat terhadap susu. Produksi dengan teknologi pasteurisasi yang paling modern dan berteknologi canggih bertujuan untuk mempertahankan kesegaran dan nilai gizi sehingga menghasilkan produk susu berkualitas baik bagi konsumen.

Selain kualitas, harga merupakan salah satu isyarat yang di gunakan konsumen dalam proses persepsi, dimana harga akan mempengaruhi penilaian konsumen tentang suatu produk. Konsumen mempunyai beberapa penilaian yang berbeda tentang harga suatu produk. Harga yang ditetapkan di atas harga pesaing akan dipandang sebagai harga yang terlalu mahal, sementara itu harga yang ditetapkan dibawah harga produk pesaing akan dipandang sebagai produk yang murah atau dipandang sebagi produk yang berkualiatas rendah. Adapun harga produk Vito Milk ini relatif murah untuk semua kalangan dari menengah kebawah hingga kalangan menengah keatas.

Kepuasan konsumen berhubungan dengan pola pembelian terhadap suatu produk. Tingkat kepuasan konsumen akan menentukan pemilihan suatu produk melalui proses keputusan pembelian, sehingga terlihat pola pembelian seseorang terhadap suatu produk. Menurut Rustanti (2015), kepuasan konsumen merupakan tingkat perasaan seseorang yang dirasakan dari suatu manfaat yang diberikan oleh produk dirasa sesuai dengan apa yang diharapkannya. Beberapa faktor yang dapat mempengaruhi kepuasan konsumen yaitu kualitas pelayanan, kualitas produk, dan harga. Kualitas pelayanan mempengaruhi kepuasan konsumen karena terjadi interaksi antarkonsumen dengan pihak perusahaan baik secara langsung maupun tidak langsung. Salah satu yang di lakukan Vito Milk untuk tetap menjaga kepuasan konsumen adalah dengan membuat produk susu pasteurisasi yang dihasilkan dari peternakan milik sendiri sehingga menghasilkan kualitas yang baik dengan harga yang mampu bersaing dengan kompetitor sejenisnya. 
Oleh karena itu, selain kepuasan pelanggan perusahaan perlu mengetahui informasi terkait loyalitas pelanggan dan pola pembelian untuk meningkatkan pemasarannya dalam memenangkan persaingan. Loyalitas Menurut Tjiptono (2011) "Perilaku pembelian ulang semata mata menyangkut pembelian merek tertentu yang sama secara berulang kali (bisa dikarenakan memang hanya satu satu nya merk yang tersedia, merk termurah dan sebagainya).

Perusahaan ini tergolong baru dalam memproduksi dan memasarkan produknya sehingga belum banyak masyarakat yang mengenal produk tersebut. Oleh karena itu, perusahaan perlu meningkatkan pemasarannya agar produk lebih dikenal oleh masyarakat.

Berbagai merek produk susu segar dengan teknologi pasteurisasi yang ada di pasar seperti susu segar menyebabkan PT Dwimitra Usaha Global perlu meningkatkan pemasarannya dengan baik terlebih produk ini masih baru. Hal ini menyebabkan persaingan antarperusahaan produk sejenis menjadi sangat ketat sehingga mengakibatkan produk ini banyak kehilangan pelanggan dan mengalami penurunan penjualan. Oleh karena itu perusahaan perlu mengetahui informasi terkait kepuasan, loyalitas dan pola pembelian konsumen untuk meningkatkan pemasarannya dalam memenangkan persaingan.

Berdasarkan uraian di atas, maka peneliti tertarik untuk mengembangkan PT. Dwimitra Usaha Global yang sebelumnya hanya memproduksi susu murni yang berasal dari peternakan milik sendiri dan menjualnya kepada koperasi menjadi memproduksi susu pasteurisasi dengan merek dagang sendiri sehingga perlu di lakukan penelitian dengan judul "Pengaruh Kemasan, Kualitas dan Harga Produk Susu Terhadap Kepuasan dan Loyalitas Pelanggan PT. Dwimitra Usaha Global".

\section{Metode}

Dalam penelitian ini penulis
menggunakan metode pendekatan penelitian secara kuantitatif. Metode kuantitatif dapat diartikan sebagai metode penelitian yang berlandaskan pada filsafat positivisme, digunakan untuk meneliti pada populasi atau sampel tertentu. Pengumpulan data menggunakan instrumen penelitian, analisis yang bersifat kuantitatif atau statistik dengan tujuan untuk menguji hipotesis yang telah ditetapkan Sugiyono (2016).

\section{Populasi dan Sampel Penelitian}

Populasi adalah wilayah generalisasi yang terdiri atas obyek/subyek yang mempunyai kuantitas dan karakteristik tertentu yang ditetapkan oleh peneliti untuk dipelajari dan kemudian ditarik kesimpulannya Sugiyono (2016). Populasi dalam penelitian ini adalah orang yang datang untuk membeli produk susu di sekitar, Jakarta Selatan.

Penentuan jumlah sampel dihitung berdasarkan pendapat Maholtra (2004) yakni jumlah sampel yang diambil dalam penelitian minimal 4 atau 5 kali jumlah atribut yang digunakan dalam penelitian, dengan demikian maka jumlah sampel yang digunakan dalam penelitian ini adalah 110 respoden berdasarkan penghitungan (22 pertanyaan $\times 5=110$ ). Pengambilan sampel jenis ini dilakukan berdasar kelompok / area tertentu Penentuan.

Sedangkan penentuan pengambilan jumlah responden (sampel) dilakukan melalui metode Accidental Sampling. Accidental Sampling merupakan teknik penelitian sampel berdasarkan kebetulan, yaitu memilih responden dengan cara mendatangi responden kemudian memilih calon responden yang ditemui secara kebetulan,

\section{Cara Pengumpulan Data}

Semua instrumen yang terdapat pada data kuesioner terlebih dahulu dilakukan uji validitas dan uji reliabilitas sebelum 
dilakukan penelitian lalu dilakukan teknik pengolahan data dengan SEM.

Pengujian dengan alat ukur yang memenuhi syarat validasi (valid) dan kehandalan (reliable) tingkat keakurasiannya untuk memudahkan dalam perhitungan data dan memiliki tingkat keakurasian yang sangat tinggi. Tujuan pengujian ini untuk menghasilkan kesimpulan yang valid dan dapat dipertanggungjawabkan

\section{Analisis Data}

Analisis model pada penelitian ini menggunakan metode Partial Least SquareStructural Equation Modelling (PLS-SEM). Analisis menggunakan metode Partial Least Square-Structural Equation Modelling (PLSSEM) meliputi 2 tahapan yaitu tahap evaluasi model pengukuran (Outer Model) dan tahap evaluasi model struktural (Inner Model). Evaluasi model pengukuran (Outer Model) terdiri dari uji validitas dan reliabilitas indikator penelitian. Evaluasi ini bertujuan mengukur hubungan antara variabel dengan indikator penyusunnya, artinya seberapa besar variabel laten mampu mengandung keragaman data yang ada dalam setiap indikator dan seberapa besar keterkaitan hubungan antara variabel laten dengan indikator-indikatornya. Dalam hal ini ada tiga aspek yang diinilai yaitu Convergent Validity, discriminant validity, dan composite reliability. Sedangkan evaluasi model struktural (Outer Model) bertujuan untuk menguji hipotesis penelitian

\section{Pengujian Outer Model}

Evaluasi model pengukuran (Outer Model) adalah evaluasi hubungan antara variabel dengan indikatornya dimana penggambarannya ditunjukan dengan anak panah dari konstruk (berbentuk elips) ke beberapa indikator (berbentuk kotak). Evaluasi kualitas pengukuran PLS-SEM dan model struktural berfokus pada metrik yang menunjukan kemampuan prediksi model. Evaluasi metrik model pengukuran ini meliputi dua tahap uji yaitu Convergent Validity dan discriminant validity.

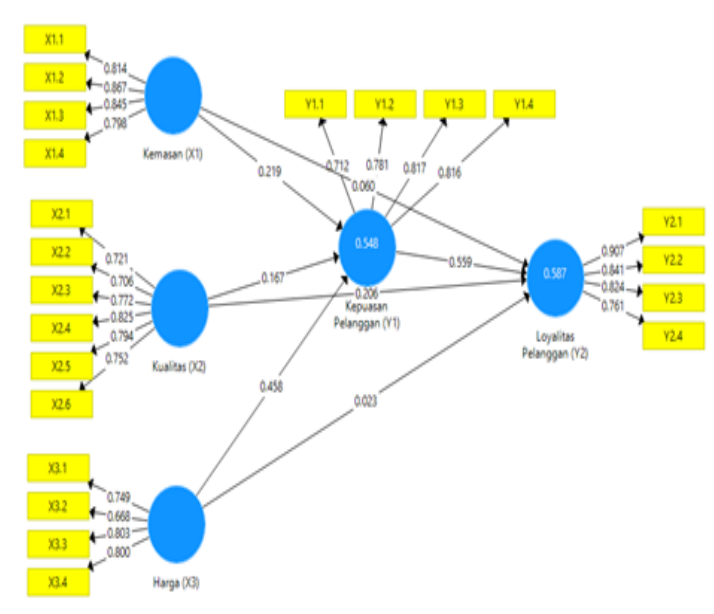

Gambar : Pengujian Inner Model

\section{Pengujian Inner Model}

Analisis Variant $\left(R^{2}\right)$ atau $U \mathrm{ji}$ Determinasi yaitu untuk mengetahui besar pengaruh variabel independen terhadap Dependen tersebut, nilai dari koefisien determinasi dapat diketahui bahwa nilai $R$ Square Kepuasan pelanggan sebesar 0.526 . Hal ini menunjukkan bahwa pengaruh kemasan, kualitas dan harga terhadap kepuasan pelanggan sebesar $52,6 \%$ dan sisanya $47.4 \%$ diterangkan oleh konstruk lainnya diluar yang diteliti dalam penelitian ini. Sedangkan $R$-Square loyalitas pelanggan sebesar 0.573 . Hal ini menunjukkan bahwa pengaruh kemasan, kualitas, harga dan kepuasan pelanggan sebesar $57,3 \%$ dan sisanya diterangkan oleh konstruk lainnya diluar yang diteliti dalam penelitian ini

\section{Pengujian Hipotesis}

Menurut Hartono (2008) dalam jogiyanto dan Abdillah (2009) menjelaskan bahwa ukuran signifikansi keterdukungan hipotesis dapat digunakan perbandingan nilai $T$-table dan T-statistic. Jika nilai $T$ statistic lebih tinggi dibandingkan $T$-table, berarti hipotesis terdukung atau diterima. Dalam penelitian ini untuk tingkat keyakinan $95 \%(\alpha=95 \%)$. Analisis dalam penelitian ini menggunakan software SmartPLS (Partial Least Square) 3.0. Melalui software tersebut dari hasil bootsrapping selanjutnya diperoleh nilai-nilai yang akan diuji. Untuk menyimpulkan apakah hipotesis 
diterima atau ditolak, digunakan harga aturan praktis yaitu T-statistic >1,96 dengan $p$-value pada signifikansi $\alpha=5 \%$ atau 0,05, jika $p$-value $<0,05$ maka $\mathrm{H}_{0}$ ditolak artinya terdapat pengaruh. Sebaliknya, jika $p$-value > 0,05 maka $\mathrm{H}_{0}$ diterima artinya tidak ada pengaruh. Evaluasi path coefficient digunakan untuk menunjukkan seberapa kuat efek atau pengaruh variabel independen kepada variabel dependen.

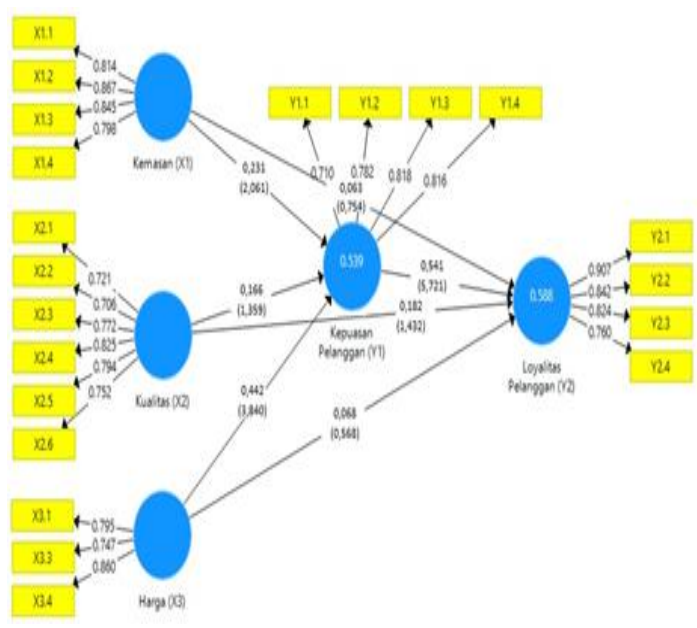

Gambar : Output Diagram Hasil

Hasil

\section{Uji Convergen Validity}

a. Nilai Convergen Validity X1 (Kemasan), semua indikatornya memiliki nilai loading faktor diatas 0,60 , dimana hal ini menunjukkan bahwa variabel ini memiliki tingkat validitas yang tinggi.

b. Nilai Convergen Validity X2 (Kualitas), semua indikatornya memiliki nilai loading faktor diatas 0,60, dimana hal ini menunjukkan bahwa variabel ini memiliki tingkat validitas yang tinggi

c. Nilai Convergen Validity X3 (Harga), semua indikatornya memiliki nilai loading faktor diatas 0,60, dimana hal ini menunjukkan bahwa variabel ini memiliki tingkat validitas yang tinggi

d. Nilai Convergen Validity Y1 (Kepuasan Pelanggan), semua indikatornya memiliki nilai loading faktor diatas 0,60 , dimana hal ini menunjukkan bahwa variabel ini memiliki tingkat validitas yang tinggi. e. Nilai Convergen Validity Y2 (Loyalitas

Pelanggan), semua indikatornya memiliki nilai loading faktor diatas 0,60 , dimana hal ini menunjukkan bahwa variabel ini memiliki tingkat validitas yang tinggi.

\section{Uji Discriminant Validity}

a. Analisa Discriminant Validity Indikator Variabel X1 (Kemasan) nilai loading indikator terhadap konstruknya pada variabel (X1) lebih besar dari pada nilai cross loading nya, maka variabel konstruk atau variabel laten sudah memiliki discriminant validity yang baik.

\section{b. Analisa Discriminant Validity}

Indikator Variabel X2 (Kualitas) nilai loading indikator terhadap konstruknya pada variabel (X2) lebih besar dari pada nilai cross loading nya, maka variabel konstruk atau variabel laten sudah memiliki discriminant validity yang baik.

\section{c. Analisa Discriminant Validity} Indikator Variabel X3 (Harga), nilai loading indikator terhadap konstruknya pada variabel (X3) lebih besar dari pada nilai cross loading nya, maka variabel konstruk atau variabel laten sudah memiliki discriminant validity yang baik.

\section{d. Analisa Discriminant Validity}

Indikator Variabel Y1 (Kepuasan Pelanggan), nilai loading indikator terhadap konstruknya pada variabel (Y1) lebih besar dari pada nilai cross loading nya, maka variabel konstruk atau variabel laten sudah memiliki discriminant validity.

e. Analisa Discriminant Validity Indikator Variabel Y2 (Loyalitas Pelanggan), nilai loading indikator terhadap konstruknya pada variabel (Y2) lebih besar dari pada nilai cross loading nya, maka variabel konstruk atau variabel laten sudah memiliki discriminant validity.

\section{Uji Average Variance Extrated (AVE)}

Nilai AVE masing-masing konstruk berada di atas 0,5, sehingga tidak ada permasalahan convergent validity sesuai tabel 1 berikut:

Tabel 1. Average Variance Extrated (AVE) 


\begin{tabular}{|l|c|}
\hline \multicolumn{1}{|c|}{ Variabel } & $\begin{array}{c}\text { Average Variance } \\
\text { Extracted (AVE) }\end{array}$ \\
\hline Harga (X3) & 0.642 \\
\hline Kemasan(X1) & 0.691 \\
\hline Kepuasan Pelanggan(Y1) & 0.613 \\
\hline Kualitas (X2) & 0.582 \\
\hline Loyalitas Pelanggan(Y2) & 0.697 \\
\hline
\end{tabular}

\section{Uji Composite Reliability}

Nilai composite reliability sudah berada diatas 0,7 maka uji reliabilitas setiap variabel laten sudah terpenuhi sesuai tabel 2 berikut:

Tabel 2. Composite Reliability

\begin{tabular}{|l|c|}
\hline \multicolumn{1}{|c|}{ Variabel } & Composite Reliability \\
\hline Harga (X3) & 0.843 \\
\hline Kemasan(X1) & 0.899 \\
\hline Kepuasan Pelanggan(Y1) & 0.863 \\
\hline Kualitas (X2) & 0.893 \\
\hline Loyalitas Pelanggan(Y2) & 0.902 \\
\hline
\end{tabular}

\section{Nilai Cronbach's Alpha}

nilai croncbacks alpha untuk semua variabel berada diatas 0,7 maka variabel laten pada penelitian ini reliabilitasnya sudah terpenuhi sesuai tabel 3 berikut:

Tabel 3. Cronbach's Alpha

\begin{tabular}{|l|c|}
\hline \multicolumn{1}{|c|}{ Variabel } & Cronbach's Alpha \\
\hline Harga (X3) & 0.721 \\
\hline Kemasan(X1) & 0.850 \\
\hline Kepuasan Pelanggan(Y1) & 0.788 \\
\hline Kualitas (X2) & 0.855 \\
\hline Loyalitas Pelanggan(Y2) & 0.854 \\
\hline
\end{tabular}

\section{Analisa Inner Model (Model Struktural)}

Analisa R-Square $\left(\boldsymbol{R}^{2}\right)$

Dari hasil perhitungan R-square adjusted Kepuasan pelanggan sebesar 0.526 . Hal ini menunjukkan bahwa pengaruh kemasan, kualitas dan harga terhadap kepuasan pelanggan sebesar $52,6 \%$ sesuai tabel 4 . Sedangkan R-square loyalitas pelanggan sebesar 0.573. Hal ini menunjukkan bahwa pengaruh kemasan, kualitas, harga dan kepuasan pelanggan sebesar $57,3 \%$. Sesuai tabel 4 berikut:

Tabel 4. R-Square $\left(R^{2}\right)$

\begin{tabular}{|l|c|c|}
\hline & R Square & $\begin{array}{c}\text { R Square } \\
\text { Adjusted }\end{array}$ \\
\hline $\begin{array}{l}\text { Kepuasan } \\
\text { Pelanggan }\end{array}$ & 0.539 & 0.526 \\
\hline $\begin{array}{l}\text { Loxalitas } \\
\text { Pelanggan }\end{array}$ & 0.588 & 0.573 \\
\hline
\end{tabular}

\section{Uji Hipotesis}

Pengujian Hipotesis Pengaruh Langsung

Hipotesis 1: nilai koefisien beta kemasan terhadap kepuasan pelanggan sebesar 0.040 dan t-statistik yaitu sebesar 2.061. Dari hasil ini dinyatakan t-statistik signifikan karena $>1,96$ dengan $p$ value $<0,05$ sehingga hipotesis diterima.

Hipotesis 2: nilai koefisien beta kemasan terhadap loyalitas pelanggan sebesar 0.740 dan t-statistik yaitu sebesar 0.754 . Dari hasil ini dinyatakan t-statistik tidak signifikan karena $<1,96$ dengan $\mathrm{p}$ value $>0,05$ sehingga hipotesis ditolak.

Hipotesis 3: nilai koefisien beta kualitas terhadap kepuasan pelanggan sebesar 0.175 dan t-statistik yaitu sebesar 1.359. Dari hasil ini dinyatakan t-statistik tidak signifikan karena $<1,96$ dengan $p$ value $>0,05$ sehingga hipotesis ditolak.

Hipotesis 4: nilai koefisien beta kualitas terhadap loyalitas pelanggan sebesar 0.153 dan t-statistik yaitu sebesar 1.432. Dari hasil ini dinyatakan t-statistik tidak signifikan karena $<1,96$ dengan $p$ value $>0,05$ sehingga hipotesis ditolak.

Hipotesis 5: nilai koefisien beta harga terhadap kepuasan pelanggan sebesar 0.000 dan t-statistik yaitu sebesar 3.840 . Dari hasil ini dinyatakan t-statistik signifikan karena $>1,96$ dengan $p$ value $<0,05$ sehingga hipotesis diterima.

Hipotesis 6: nilai koefisien beta harga terhadap loyalitas pelanggan sebesar 0.570 dan t-statistik yaitu sebesar 0.568. Dari hasil ini dinyatakan t-statistik tidak signifikan karena $<1,96$ dengan $p$ value $>0,05$ sehingga hipotesis ditolak.

Hipotesis 7: nilai koefisien beta kepuasan pelanggan terhadap loyalitas pelanggan sebesar 0.000 dan t-statistik yaitu sebesar 5.721. Dari hasil ini dinyatakan t-statistik 
signifikan karena $>1,96$ dengan $\mathrm{p}$ value $<$ 0,05 sehingga hipotesis diterima.

Pembahasan hasil analisa deskriptif bertujuan untuk mendapatkan pemahaman yang lebih lengkap mengenai variabelvariabel penelitian yang dipersepsikan oleh responden. Pembahasan dilakukan dengan cara menafsirkan atau menginterpretasikan nilai rata-rata dari masing-masing indikator pada masing-masing variabel dengan menggunakan unit analisis individu.

Pembahasan dilakukan khusus dilakukan untuk menguji dan menjelaskan pengaruh antara kemasan terhadap kepuasan pelanggan, pengaruh antara kemasan terhadap loyalitas pelanggan, pengaruh antara kualitas terhadap kepuasan pelanggan, kualitas terhadap loyalitas pelanggan, harga terhadap kepuasan pelanggan, harga terhadap loyalitas pelanggan, pengaruh kepuasan pelanggan terhadap loyalitas pelanggan. Dasar Interpretasi yang digunakan dalam penelitian ini mengacu pada presentase dari jawaban responden.

Semakin berkembangnya sistem teknologi dan informasi serta komunikasi, membuat semakin terbukanya kompetisi yang berat, dengan demikian setiap perusahaan akan bekerja keras untuk usahanya dalam memuaskan pelanggan sehingga perusahaan tersebut mendapatkan pelanggan yang loyal. Lebih disebabkan karena pelanggan yang semakin cerdas, sadar harga, dan banyak menuntut, informasi yang banyak didapat diakses pelanggan dan juga banyak informasi produk lain yang dapat diakses pelanggan sehingga membuat pelanggan semakin "dimanjakan" oleh pilihan produk via internet.

Kondisi tersebut menyebabkan pelanggan memiliki pilihan yang lebih banyak dalam menggunakan uang yang dimilikinya. Perkembangan teknologi, berkembangnya dunia pendidikan, serta penghasilan masyarakat menjadikan masyarakat menjadi menuntut untuk diberikan pelayanan yang baik sehingga pelanggan menjadi "puas" dengan apa yang didapat. Kotler (2007: 25) mengartikan tingkat kepuasan sebagai fungsi dari perbedaan antara kinerja yang dirasakan berbeda oleh pelanggannya dengan harapan. Maksutnya adalah dari pilihan tersebut jika perusahaan mendapatkan dua organisasi pada jenis bisnis yang sama dapat dinilai.

Umumnya Konteks kepuasan pelanggan adalah harapan dari pelanggan yang merupakan keyakinan atau perkiraan pelanggan tersebut tentang apa yang akan diterimanya yagn diungkapkan baik lisan maupun non lisan. Harapan pelanggan dibentuk oleh pengetahuan dan juga pengalaman pembelian sebelumnya. Harapan - harapan pelanggan tersebut diatas dari waktu ke waktu berkembang seiring dengan semakin bertambahnya pengalaman dan pengetahuan pelanggan, pada dasarnya harapan pelanggan yang paling utama adalah kepuasan pelanggan lebih memikirkan apa yang akan dibelinya dapat memuaskannya sesuai dengan kebutuhan pelanggan tersebut sebagai dasar pelanggan untuk membeli.

Semua perusahaan baik barang maupun jasa, sudah barang tentu harus menyadari tentang kepuasan pelanggan, dan kepuasan pelanggan harus dicapai oleh perusahaan tersebut, dalam rangka untuk mendapatkan pelanggan yang loyal, Menurut Ali Hasan (2008) Loyalitas pelanggan dedefinisikan sebagai orang yang membeli, khususnya yang membeli secara teratur dan berulang-ulang. Pelanggan merupakan seseorang yang terus menerus dan berulang kali datang ke suatu tempat yang sama untuk memuaskan keinginannya dengan memiliki suatu produk atau mendapatkan suatu jasa dan membayar produk atau jasa tersebut. Dan selanjutnya dalam kepuasan bahwa pelanggan tidak hanya membeli produk tetapi juga membeli pelayanan.

Pada variable Kemasan terdapat nilai yang rendah pada indikator kemasan yang mudah di bawa, di jinjing dan di pegang (X1.4) dengan persentase 79,8\% maka untuk 
dapat meningkatkan penjualan produk vito milk, bentuk kemasan harus lebih di tingkatkan lagi.

Pada Variabel Kualitas terdapat nilai yang rendah pada indikator kehigienisan produk (X2.2) dengan persentase 70,6\% maka untuk dapat meningkatkan penjualan produk vito milk perlu menjaga kualitas susu tetap higienis dan salah satunya dengan menggunakan kemasan yg dapat di buka dan ditutup kembali dengan mudah.

Pada Variabel harga terdapat nilai yang rendah pada indikator daya saing harga produk (X3.3) dengan persentase 74,7\% maka untuk dapat meningkatkan penjualan produk vito milk perlu terus menjaga harga produk vito milk agar tetap dibawah kompetitor sejenis yang memiliki merk lebih dikenal.

Pada Variabel kepuasan pelanggan terdapat nilai yang rendah pada indikator kualitas produk yang dihasilkan (Y1.1) dengan persentase $71,0 \%$ maka untuk dapat menjaga kepuasan konsumen dan meningkatkan penjualan perlu meningkatkan kualitas produk susu vito milk agar mampu bersaing dengan kompetitor sejenis.

Pada Variabel loyalitas pelanggan terdapat nilai yang rendah pada indikator pelanggan mengajak orang lain untuk mencoba produk (Y2.4) dengan persentase $76,0 \%$ maka perlu melakukan menjaga kualitas susu minimal sama dengan kompetitor yang sudah memiliki nama besar sehingga konsumen mengajak orang lain untuk mencoba produk vito milk yang dari segi kualitas dan rasa sama dengan kompetitor sejenis namun harga lebih murah.

\section{Kesimpulan}

1. Kemasan berpengaruh signifikan terhadap kepuasan pelanggan. Hal ini berarti bahwa peningkatan atau penurunan kemasan akan mempengaruhi peningkatan atau penurunan kepuasan pelanggan.
2. Kemasan berpengaruh tidak signifikan terhadap loyalitas pelanggan. Hal ini berarti Untuk dapat memiliki pelanggan yang loyal maka perlu melakukan perbaikan dan inovasi terhadap kemasan.

3. Kualitas berpengaruh tidak signifikan terhadap kepuasan pelanggan. Hal ini berarti bahwa pelanggan belum tentu merasa puas apabila produk yang mereka beli berkualitas baik.

4. Kualitas berpengaruh tidak signifikan terhadap loyalitas pelanggan. Hal ini berarti bahwa pelanggan belum tentu loyal terhadap produk susu ini, jika ia mendapatkan susu pasteurisasi yang berkualitas.

5. Harga berpengaruh signifikan terhadap kepuasan pelanggan. Hal ini berarti terdapat hubungan positif antara harga dengan kepuasan pelanggan.

6. Harga berpengaruh tidak signifikan terhadap loyalitas pelanggan. Hal ini berarti bahwa produk ini memiliki harga yang terjangkau, namun menurut konsumen harga yang murah belum di tunjang dengan kemasan yang mudah untuk di buka dan ditutup kembali agar tetap higienis sehingga pelanggan masih membeli produk kompetitor sejenis lain.

7. Kepuasan pelanggan berpengaruh signifikan terhadap loyalitas pelanggan. Hal ini berarti bahwa pelanggan akan bersedia untuk mengajak orang lain untuk mencoba produk ini, dan bersedia untuk merekomendasikan produk ini kepada orang lain. 


\section{Daftar Pustaka}

1. Ancok, D. (2003). Teknik Penyusunan Skala Pengukuran. Yogyakarta: Andi Offset.

2. Arikunto, S. (2002). Metodologi Penelitian Suatu Pendekatan Proposal. Jakarta: PT. Rineka Cipta..

3. Assauri, S. (2011). Strategic Management, Sustainable Competitive Advantages, Lembaga Management Fakultas Ekonomi Universitas Indonesia, Jakarta

4. Fandy, Tjiptono. (2008). Strategi Pemasaran, Edisi III, Yogyakarta : CV. Andi Offset

5. Fandy, Tjiptono. (2011). Service Management Mewujudkan Layanan Prima. Edisi 2. Yogyakarta: Andi.

6.Ghozali, Imam, (2011), Structural Equation Modeling Metode Alternatif Dengan Partial Least Square (PLS) Edisi 3, Badan Penerbit Universitas Diponegoro. Semarang.

7.Griffin, Jill. (2010). Customer Loyalty, Menumbuhkandan Mempertahankan Kesetiaan Pelanggan. Alih Bahasa Dwi Kartini Yahya. Jakarta: Erlangga.

8.Handoko. (2002). Manajemen Pemasaran. Badan penerbit IPWI. Jakarta.

9.Kusumasasti, Ika. (2017). yang berjudul Pengaruh Kualitas Produk Dan Layanan Terhadap Loyalitas Pelanggan DW Coffee Shop.

10. Klimchuk, M.R. dan Krasovec, S.A. (2006). Packaging Desain Successful Product Branding From Concept to Shelf. New Jersey: Jhon Wiley \& Sons Inc.
11. Kotler, Philip. (1999). Manajemen Pemasaran. Jilid II. Edisi Milenium. Jakarta: PT. Prenhallindo

12. Kotler, Philip and Gary Armstrong. (2012). Prinsip-prinsip Pemasaran. Edisi 13. Jilid 1. Jakarta: Erlangga.

13. Kotler, P. dan Kevin Lane Keller. (2012), Manajemen Pemasaran ed.Ketiga Belas . Jilid 2 Terjemahan oleh BOB Sabran MM : Penerbit Erlangga.

14. Kotler, P., \& Amstrong, G. (2012). Principles of Marketing Edisi 14, Global Edition.Pearson Prentice Hall.

15. Kotler, Philip and Kevin Lane Keller, (2016). Marketing Managemen, 15th Edition, Pearson Education,Inc.

16. Maiqel, Efendi. (2015). Pengaruh Merk, Kemasan dan Desain Produk terhadap Loyalitas Pelanggan produk susu PT.Ultra Jaya (studi pada pelanggan produk susu Ultra di Kirana Mart Gampengrejo Kediri)

17. Malhotra, N.K. (2004). Riset Pemasaran, Pendekatan Terapan. Edisi Bahasa Indonesia, PT. Indeks Kelompok Gramedia, Jakarta.

18. Mario Christo Pesoth. (2015). Pengaruh Kualitas Produk, Packaging, Dan Brand Image Terhadap Kepuasaan Pelanggan Pada Perusahaan Rokok Dunhill Di Kota Manado.

19. Maksum, Ali. (2012). Metodologi Penelitian dalam Olahraga. Surabaya: Unesa University Press.

20. Nasution, M. N. (2005). Manajemen Mutu Terpadu: Total Quality Management, Edisi Kedua, Ghalia Indonesia, Bogor. 
21. Ni Putu Cempaka Dharmadewi Atmaja (2016) Pengaruh Kewajaran Harga, Citra Perusahaan Terhadap Kepuasan Dan Loyalitas Pengguna Jasa Penerbangan Domestik Garuda Indonesia Di Denpasar.

22. Putra dan Ngatno (2017). pengaruh kualitas pelayanan terhadap loyalitas pelanggan melalui kepuasan pelanggan sebagai variable intervening (Studi kasus pada Pelanggan PT. Lontar Media Digital Printing Semarang)

23. Rangkuti, Freddy. (2010). Strategi Promosi Yang Kreatif dan Analisis Kasus IntegratedMarketing Communication, Gramedia Pustaka Utama, Jakarta.

24. Rustanti, N. (2015). Buku Ajar Ekonomi Pangan dan Gizi. Deepublish: CV. Bening Utama. Yogyakarta.

25. Simamora Bilson. (2007). Panduan Riset dan Perilaku Konsumen. Jakarta :PT Gramedia Pustaka Utama.

26. Soeratno dan Lincolin Arsyad. (1999). Metodologi Penelitian Untuk Ekonomi dan Bisnis. Ed. Revisi. Yogyakarta: (UPP) AMP YKPN.

27. Supomo, Bambang dan Nur Indriantoro (2002). Metodologi Penelitian Bisnis, Cetakan Kedua, Yogyakara; Penerbit BFEE UGM.

28. Stanton, Wiliam J. (1998). Prinsip Pemasaran Edisi Ketujuh Jilid 1. Jakarta: Erlangga.
29. Sugiyono. (2016). Metode Penelitian Kuantitatif, Kualitatif dan R\&D. Bandung: PT Alfabet.

30. Syarif Maulana, Ade (2016). Pengaruh Kualitas Pelayanan dan Harga terhadap Kepuasan Pelanggan PT. TOI.

31. Vincent,Gaspersz. (2008). Total Quality Managament. Jakarta: Penerbit Gramedia Pustaka Utama.

32. Widyastuti Tri (2017). pengaruh harga dan kualitas produk terhadap kepuasan pelanggan tempe di pasar lembang Tangerang.

33. Wirya, Iwan. (1999). Kemasan yang Menjual. Jakarta : PT. Gramedia Pustaka Utama.

34. Yee, Yeung, dan Cheng (2010) production economics an empirical study of employee loyalty, service quality and firm performance in the service industry.

35.Yulisetiarini (2016). the effect of relationship marketing towards costumer satisfaction and customer loyalty on franchised retails in East Java.

35. Zeithaml, Valarie, Bitner \& Gremler. (2003). Services Marketing Integrating Customer Focus Across the Firm Third Edition. New York: McGraw Hill. 